\title{
VATS lobectomy vs. open lobectomy for early-stage lung cancer: an endless question-are we close to a definite answer?
}

\author{
Francesco Guerrera $^{1,2}$, Anne Olland ${ }^{3,4,5}$, Enrico Ruffini ${ }^{1,2}$, Pierre-Emmanuel Falcoz ${ }^{3,4,5}$ \\ ${ }^{1}$ Department of Surgical Science, University of Torino, Turin, Italy; ${ }^{2}$ Department of Thoracic Surgery, A.O.U. Città Della Salute e Della Scienza di \\ Torino, Turin, Italy; ${ }^{3}$ Department of Thoracic Surgery, Strasbourg University Hospital, Strasbourg, France; ${ }^{4}$ INSERM (French National Institute of \\ Health and Medical Research), UMR 1260, Regenerative Nanomedicine (RNM), FMTS, Strasbourg, France; ${ }^{5}$ Faculty of Pharmacy and Medicine, \\ University of Strasbourg, Strasbourg, France \\ Correspondence to: Pierre-Emmanuel Falcoz. Department of Thoracic Surgery, Strasbourg University Hospital, 1 place de l'Hôpital, BP 426, 67091 \\ Strasbourg Cedex, France. Email: pefalcoz@gmail.com. \\ Provenance: This is an invited article commissioned by the Academic Editor Xianglin Hu (Department of Pulmonary Medicine, Zhongshan Hospital, \\ Fudan University, Shanghai, China). \\ Comment on: Yang CJ, Kumar A, Klapper JA, et al. A National Analysis of Long-term Survival Following Thoracoscopic Versus Open Lobectomy for \\ Stage I Non-small-cell Lung Cancer. Ann Surg 2019;269:163-71.
}

Submitted Oct 19, 2019. Accepted for publication Nov 25, 2019.

doi: $10.21037 /$ jtd.2019.12.19

View this article at: http://dx.doi.org/10.21037/jtd.2019.12.19

Initially described in 1992 (1), thoracoscopic (VATS) lobectomy is unquestionably the greatest upheaval in thoracic surgery community since the introduction of one-lung ventilation by Carlens in 1949 (2).In the last twenty years, after several initial uncertainty about its adoption, VATS lobectomy slowly but constantly propagates worldwide and, nowadays, most international guidelines suggest the adoption of this minimally invasive approach for early-stage lung cancer, over the traditional "open" approaches $(3,4)$. Indeed, several single- and multi-institutional studies, as well as national registry analysis, showed that VATS lobectomy adoption permits a shorter chest tube duration, a shorter length of hospital stay, fewer postoperative complications, and a lower or comparable perioperative mortality $v s$. classic thoracotomy (5-13). Moreover, the recent results of UK multicentric VIOLET randomized controlled trial corroborated these statements, demonstrating an association between VATS lobectomy and enhanced short-term clinical outcomes when compared with open surgery for non-small cell lung cancer (NSCLC) $(14,15)$.

Nevertheless, even if VATS lobectomy adoption is constantly increasing, its diffusion was not as fast as anticipated. For instance, VATS lobectomy rates were 30\% in Europe (16), 50\% in Italy (17), 65\% in Denmark (18), $29 \%$ in Great Britain and Ireland (19), and $30-40 \%$ in the USA (20). This retard in VATS lobectomy adoption, was initially imputable to the skepticism concerning the reliability and the safety of the technique, compared to the well-established thoracotomy approaches. Currently, the major concerns are represented by short- and long-term oncologic results, that are closely correlated with long-term survival (21).

In this scenario, we read with great interest the recent article by Yang et al. presenting the results of the first national analysis assessing long-term outcomes of VATS versus open lobectomy in stage I NSCLC (22). Actually, the previous analysis of national registry couldn't define long-term outcomes due to data unavailability (5-12). Moreover, as secondary endpoint, the authors present short term results, including oncological surrogates' outcomes like pathologic nodal upstaging, lymph node retrieval and surgical margin positivity.

The authors reported no significant differences for 5-year overall survival between the VATS and open lobectomy, in both multivariable-adjusted survival analysis (HR: 0.95; 95\% CI: 0.86-1.05) and propensity score-matched survival analysis (5-year survival: VATS $66.3 \%$ vs. Opens $65.8 \%$ ). This result is consistent with the current literature, that, so far, was merely based on smaller mono-institutional reports.

Moreover, the authors address another point of particular concern, as the quality of lymph node assessment. Undeniably, while all the current guidelines underline the 
prominence of lymph node assessment, this procedure is not regularly performed as it should. In particular, American College of Surgeons and US Surveillance, Epidemiology, and End Results (SEER) reported that mediastinal lymph nodes are rarely investigated in the majority of surgical procedures $(23,24)$. In this context, nodal upstaging is considered one of the indexes of the oncological quality of the resection. Unfortunately, the current literature is inconsistent regarding this topic: several studies showed no differences in nodal upstaging between VATS and open lobectomy $(25,26)$, while other reported a reduced nodal upstaging in VATS lobectomy procedures $(12,21,27)$. In the present article, the results indicated that there were no significant differences in nodal upstaging between VATS and open lobectomy procedures; and these findings were confirmed if considered the $\mathrm{N} 0$ to $\mathrm{N} 1$ and the $\mathrm{N} 0$ to $\mathrm{N} 2$ upstaging. These results suggested an equivalence in oncologic efficacy of VATS lobectomy as compared to open approaches, once overcome the initial learning curve.

Certainly, stronger evidence on short-term outcomes will be soon provided by the VIOLET study that showed similar results reporting a comparable rate of nodal upstaging between VATS and open lobectomy groups (15). On the other hand, we believe that with the continuous spread of VATS lobectomy adoption, and the parallel enhance of surgeon expertise with the technique, most of the future evidences will converge in defining the oncological equivalence of VATS and open lobectomy for early-stage lung cancer.

Definitively, the study of Yang and colleagues represents a step forward in this the definition of oncologic equivalency between VATS and open lobectomy procedure. It is worthy to note that in the present article, only about $20 \%$ of patients were submitted to a VATS lobectomy, underlining the resiliency of the surgeons to abandon the open approaches (22). We hope that the results presented in this study could stimulate the production of evidence concerning oncological quality of VATS lobectomy procedures and could dissipate concern that still slows down its adoption worldwide.

\section{Acknowledgments}

None.

\section{Footnote}

Conflicts of Interest: The authors have no conflicts of interest to declare.

Ethical Statement: The authors are accountable for all aspects of the work in ensuring that questions related to the accuracy or integrity of any part of the work are appropriately investigated and resolved.

\section{References}

1. Roviaro G, Rebuffat C, Varoli F, et al. Videoendoscopic pulmonary lobectomy for cancer. Surg Laparosc Endosc 1992;2:244-7.

2. Carlens E. A new flexible double-lumen catheter for bronchospirometry. J Thorac Surg 1949;18:742-6.

3. Howington JA, Blum MG, Chang AC, et al. Treatment of stage I and II non-small cell lung cancer: Diagnosis and management of lung cancer, 3 rd ed: American College of Chest Physicians evidence-based clinical practice guidelines. Chest 2013;143:e278S-e313S.

4. Ettinger DS, Wood DE, Aisner DL, et al. NCCN guidelines insights: non-small cell lung cancer, Version 3.2019. January 18, 2019. Available online: https://www. nccn.org/professionals/physician_gls/default.aspx

5. Laursen LØ, Petersen RH, Hansen HJ, et al. Videoassisted thoracoscopic surgery lobectomy for lung cancer is associated with a lower 30-day morbidity compared with lobectomy by thoracotomy. Eur J Cardiothorac Surg 2016;49:870-5.

6. Paul S, Altorki NK, Sheng S, et al. Thoracoscopic lobectomy is associated with lower morbidity than open lobectomy: a propensity-matched analysis from the STS database. J Thorac Cardiovasc Surg 2010;139:366-78.

7. Paul S, Sedrakyan A, Chiu YL, et al. Outcomes after lobectomy using thoracoscopy vs thoracotomy: a comparative effectiveness analysis utilizing the Nationwide Inpatient Sample database. Eur J Cardiothorac Surg 2013;43:813-7.

8. Pagès PB, Delpy JP, Orsini B, et al. Propensity score analysis comparing videothoracoscopic lobectomy with thoracotomy: a French nationwide study. Ann Thorac Surg 2016;101:1370-8.

9. Falcoz PE, Puyraveau M, Thomas PA, et al. Videoassisted thoracoscopic surgery versus open lobectomy for primary non-small-cell lung cancer: a propensitymatched analysis of outcome from the European Society of Thoracic Surgeon database. Eur J Cardiothorac Surg 2016;49:602-9.

10. Boffa DJ, Dhamija A, Kosinski AS, et al. Fewer 
complications result from a video-assisted approach to anatomic resection of clinical stage I lung cancer. J Thorac Cardiovasc Surg 2014;148:637-43.

11. Paul S, Isaacs AJ, Treasure T, et al. Long term survival with thoracoscopic versus open lobectomy: propensity matched comparative analysis using SEER-Medicare database. BMJ 2014;349:g5575.

12. Medbery RL, Gillespie TW, Liu Y, et al. Nodal upstaging is more common with thoracotomy than with VATS during lobectomy for early-stage lung cancer: an analysis from the national cancer data base. J Thorac Oncol 2016;11:222-33.

13. Yang HX, Woo KM, Sima CS, et al. Long-term survival based on the surgical approach to lobectomy for clinical stage I nonsmall cell lung cancer: comparison of robotic, video-assisted thoracic surgery, and thoracotomy lobectomy. Ann Surg 2017;265:431-7.

14. Lim E. VIdeo assisted thoracoscopic lobectomy versus conventional Open LobEcTomy for lung cancer, a multicentre randomised controlled trial with an internal pilot The VIOLET study. Available online: http://www.nets. nihr.ac.uk/_data/assets/pdf_file/0008/144566/PRO-1304-03.pdf (last consulted 1176/11/2016).

15. Lim E, et al. In Hospital Clinical Efficacy, Safety and Oncologic Outcomes from VIOLET: A K Multi-Centre RCT of VATS Versus Open Lobectomy for Lung Cancer. Available online: https://library.iaslc.org/conferenceprogram?product_id=15

16. ESTS database report. Available online: http://www. ests.org/login.aspx?ReturnUrl=\%2fprivate \%2fdatabase_ reports.aspx

17. Passiglia F, Calandri M, Guerrera F, et al. Lung cancer in Italy. J Thorac Oncol 2019. In press.

18. Jakobsen E, Rasmussen TR. The Danish Lung Cancer
Cite this article as: Guerrera F, Olland A, Ruffini E, Falcoz PE. VATS lobectomy vs. open lobectomy for early-stage lung cancer: an endless question-are we close to a definite answer? J Thorac Dis 2019;11(12):5616-5618. doi: 10.21037/jtd.2019.12.19
Registry. Clin Epidemiol 2016;8:537-41.

19. Society of Cardiothoracic Surgery Report. Available online: http://scts.org/outcomes/thoracic

20. Abdelsattar ZM, Allen MS, Shen KR, et al. Variation in Hospital Adoption Rates of Video-Assisted Thoracoscopic Lobectomy for Lung Cancer and the Effect on Outcomes. Ann Thorac Surg 2017;103:454-60.

21. Licht PB, Jorgensen OD, Ladegaard L, et al. A national study of nodal upstaging after thoracoscopic versus open lobectomy for clinical stage I lung cancer. Ann Thorac Surg 2013;96:943-9.

22. Yang CJ, Kumar A, Klapper JA et al. A National Analysis of Long-term Survival Following Thoracoscopic Versus Open Lobectomy for Stage I Non-small-cell Lung Cancer. Ann Surg 2019;269:163-71.

23. Little AG, Rusch VW, Bonner JA, et al. Patterns of surgical care of lung cancer patients. Ann Thorac Surg 2005;80:2051-6.

24. Osarogiagbon RU, Yu X. Mediastinal lymph node examination and survival in resected early-stage non-smallcell lung cancer in the surveillance, epidemiology, and end results database. J Thorac Oncol 2012;7:1798-806.

25. Yang CF, Sun Z, Speicher PJ, et al. Use and outcomes of minimally invasive lobectomy for Stage I non-small cell lung cancer in the National Cancer Data Base. Ann Thorac Surg 2016;101:1037-42.

26. D'Amico TA, Niland J, Mamet R, et al. Efficacy of mediastinal lymph node dissection during lobectomy for lung cancer by thoracoscopy and thoracotomy. Ann Thorac Surg 2011;92:226-31.

27. Boffa DJ, Kosinski AS, Paul S, et al. Lymph node evaluation by open or videoassisted approaches in 11,500 anatomic lung cancer resections. Ann Thorac Surg 2012;94:347-53. 